\title{
Unravelling the Mystery of Regional Unemployment in Finland
}

\author{
PETRI BÖCKERMAN \\ Labour Institute for Economic Research, Pitkänsillanranta 3A, FIN-00530 Helsinki, Finland. \\ Email:petri.bockerman@labour.fi
}

(Received December 2001; in revised form October 2002)

Böckerman P. (2003) Unravelling the mystery of regional unemployment in Finland, Reg. Studies 37, 331-340. The study explores the determination of regional unemployment in Finland. The evaluation of regional labour markets is based on unique, linked panel data that is created by matching the conventional economic fundamentals with the measures based on gross flows of jobs and workers. The striking empirical finding is that the reorganization of labour markets lowers the unemployment rate in the Finnish regions. In other words, the reallocation of labour resources seems to be good for regional employment.

Restructuring Reorganization Unemployment Gross flows Regional labour markets

BÖCKERMAN P. (2003) Démystifier le chômage régional en Finlande, Reg. Studies 37, 331-340. Cette étude cherche à examiner la détermination du chômage régional en Finlande. L'évaluation des marchés du travail est fondée sur des données uniques rassemblées auprès des échantillons permanents liées et obtenues en mettant en rapport les fondements économiques conventionnels avec les mesures basées sur les flux bruts d'emplois et des travailleurs. La conclusion empirique à noter c'est que la réorganisation des marchés du travail réduit le taux de chômage régional. Autrement dit, la redistribution des ressources humaines semble avantageux pour l'emploi régional.

Restructuration Réorganisation Chômage Flux bruts Marchés du travail régionaux

\section{INTRODUCTION}

Regional labour markets have gained a growing interest in Finland. The reason is that there has been a rapid rise in the regional disparities in unemployment rates as part of the export-led recovery from the great slump of the early 1990s (see, for example, PeHKONEN and Tervo, 1998; Tervo, 1998). As a consequence of this development, the regional unemployment disparities across the 20 Finnish provinces measured by the standard deviation of unemployment rates were approximately four times higher in 1997 compared with the situation before the great slump of the early 1990s.

Despite the apparent importance of regional labour markets, detailed empirical studies that aim to relate the regional unemployment disparities to the underlying
BÖCKERMAN P. (2003) Lösung des Rätsels regionaler Erwerbslosigkeit in Finnland, Reg. Studies 37, 331-340. Diese Studie untersucht, wodurch regionale Erwerbslosigkeit in Finnland bestimmt wird. Die Bewertung des regionalen Arbeitsmarktes stützt sich auf einmalige, miteinander verknüpfte Datenlisten, die durch gegeseitiges Abstimmen von üblichen wirtschaftlichen Grundlagen auf die Maßnahmen geschaffen wurden, die auf Gesamtflüssen von Stellen und Arbeitskräften beruhen. Der bemerkenswerte Befund besteht darin, daß die Neuordnung der Arbeitsmärkte die Erwerbslosenrate in den finnischen Regionen senkt. In anderen Worten: die Neuzuteilung von Arbeitskräften scheint der regionalen Erwerbstätigkeit gut zu tun.

Umstrukturierung Umorganisation Erwerbslosigkeit Regionale Arbeitsmärkte

economic fundamentals in Finland have not been available. In particular, the existing empirical studies exclude an evaluation of the impact of restructuring in terms of gross flows of jobs and workers on the regional unemployment rates. ${ }^{2}$ This notion seems to extend to the whole of the literature on regional unemployment disparities (see, for example, ElHORst, 2003).

Regional economies are in a state of continuous turbulence. The continuous reallocation and the reorganization of scarce resources culminate in the functioning of labour markets, where the reallocation of resources takes the form of gross job flows (i.e. job creation and destruction), and gross worker flows (i.e. hirings and separations of workers) (see, for example, Davis and Haltiwanger, 1999). The reorganization view of regional labour markets underlines the stylized feature that the pool of available jobs is not 
stagnant over time. This restructuring at the plant level of the regions is most likely linked to the regional unemployment problem.

This empirical study aims, therefore, to relate the regional unemployment disparities to the economic fundamentals in Finland. Along with the conventional economic fundamentals suggested by the available empirical literature on regional unemployment disparities, the study considers the internal turnover in the regional labour markets measured by gross job and worker flows based on the establishment-level dynamics of labour-demand adjustment. In addition, the study includes an elaboration of the turnover between regional labour markets measured by gross migration flows on the regional unemployment rates. ${ }^{3}$ By doing this, the study fills an important gap in the literature on regional labour markets in Finland and provides detailed empirical evidence for the importance of restructuring from the regional perspective.

The rest of the study is organized as follows. The second section provides the definitions of gross flows of jobs and workers. The third section provides a survey of the literature that has analysed the connection of restructuring and unemployment from the regional perspective. The fourth section provides a theoretical background and motivation for the role of restructuring based on gross flows of jobs and workers. The fifth section of the study includes a description of the linked data that is used to address the determination of the unemployment rate in the Finnish regions. The sixth section reports the results and the last section concludes.

\section{GROSS FLOWS OF JOBS AND WORKERS}

The gross flows of jobs and workers are measured as the number of jobs created or destroyed or workers moving in and out of establishments (i.e. hirings and separations of workers) (see DAVIs et al., 1996). This means that the measure of the job creation rate is calculated as follows:

$$
J C_{t}=\sum_{i} \Delta E_{i t}^{+} /\left(\left(\sum_{i} E_{i t}+\sum_{i} E_{i, t-1}\right) / 2\right)
$$

where: $E$ denotes employment in plant $i$ year $t$ and the superscript ' + ' refers to positive changes. To convert time $-t$ job flow measures to rates, job creation and destruction are divided by the average of employment at $t$ and $t-1$ in order to achieve technical advantages over more conventional growth rate measures. ${ }^{4}$

The measure of the job destruction rate is calculated as follows:

$$
J D_{t}=\left|\sum_{i} \Delta E_{i t}^{-}\right| /\left(\left(\sum_{i} E_{i t}+\sum_{i} E_{i, t-1}\right) / 2\right)
$$

Thus, the job destruction rate is defined as the absolute value of the sum of negative employment changes, divided by the average number of employees. The superscript '-' refers to negative changes. The Appendix (section a) provides an example of the calculation of regional gross flows of jobs. ${ }^{5}$

The definitions of job creation and destruction mean that the net rate of change of employment (NET) is simply the difference of the measures of job creation and destruction:

$$
N E T_{t}=J C_{t}-J D_{t}
$$

The sum of job creation and destruction rates is called the gross job reallocation rate $(J R)$ :

$$
J R_{t}=J C_{t}+J D_{t}
$$

The excess job reallocation rate $(E J R)$ equals (gross) job reallocation minus the absolute value of the net employment change:

$$
E J R_{t}=J R_{t}-\left|N E T_{i}\right|
$$

This means that the excess job reallocation rate is an index of simultaneous gross job creation and destruction. CabAller O, 1998, notes that, for this reason, it is appropriate to measure the magnitude of restructuring by the excess reallocation rate. In other words, so-called excess job reallocation provides a coherent measure of structural change or restructuring among the plants of the regions. In addition, it is a natural measure of heterogeneity in the plant-level employment outcome among plants. If excess job reallocation is above zero, then the magnitude of gross job reallocation is above what has been necessary to accommodate the net employment changes of regional labour markets.

The excess job reallocation rate is, therefore, a measure that captures the internal reorganization of the regions. The novelty of the following empirical investigation is that the turnover between regional labour markets is measured in the same way as the rate of excess job reallocation. This means that the applied measure of external turnover is based on the notion that the magnitude of simultaneous gross migration flows is an appropriate measure for the intensiveness of reorganization across regional labour markets. ${ }^{6}$

Comparison of information in two consecutive years can be used for calculating the number of employees who have entered a plant during the year and are still working at the same plant. The sum of these employees over all plants is worker inflow, or hiring. It is also possible to identify those employees who are no longer working at a plant. This means that the sum of these employees is worker outflow, or separation.

Dividing the worker inflow and outflow in a period of time by the average of employment in periods $t$ and $t-1$ delivers the worker inflow rate $(W I F)$ and the worker outflow rate $(W O F)$. The difference between $W I F$ and $W O F$ is the net rate of change in employment:

$$
N E T_{t}=W I F_{t}-W O F_{t}
$$


The worker flow rate $(W F)$ is simply the sum of the hiring $(W I F)$ and separation $(W O F)$ rates. In addition, the so-called churning rate $(C F)$ can be defined as follows:

$$
C F_{t}=W F_{t}-J R_{t}
$$

These definitions mean that the churning rate ties worker flows and job flows together and, therefore, completes the picture of the dynamics of labour adjustment at the establishment level. In particular, the churning rate is an appropriate measure of the internal reorganization of the regional labour markets, because the measure captures the fact that the available vacancies of regional labour markets are subject to various idiosyncratic shocks within plants. This is due to the comparison of worker flows with job flows. The churning rate can indeed be called the 'excess worker turnover rate'. Thus, an increase in the rate of churning means that there is more reshuffling by workers that is not directly related to job creation and destruction.

\section{PREVIOUS RELATED STUDIES}

Naturally, there have been a great number of earlier empirical studies on the nature and consequences of the so-called structural change on the levels of employment and unemployment. Those studies heavily emphasize the notion that the reallocation of labour resources is one of the most important sources of unemployment. Restructuring is typically associated with shifts in the shares of industries or certain components of labour demand. In particular, LILIEN, 1982, documented a strong, positive time-series relationship between aggregate unemployment and the crossindustry dispersion of employment growth rates as an indication of large-scale sectoral shifts of the US economy. Afterwards, ABRAham and KAtz, 1986, questioned this interpretation of the correlation. ${ }^{7}$

However, the available empirical applications based on the tradition started by LILIEN, 1982, tend to apply aggregate data. In addition, the number of empirical studies that look at restructuring and employment from the regional perspective is limited. The main conclusion of the existing literature is that an increase in the rate of labour reallocation is also a source of regional unemployment. However, the literature has certainly not stressed the issue of restructuring by applying the concepts of gross flows of jobs and workers that can be used to capture structural change at the plant level of the regions.

The existing literature can be summarized in a nutshell as follows. HolzER, 1991, pays attention to restructuring in connection with regional unemployment. The study analyses the effects of demand shifts within and between local labour markets on employment and unemployment outcomes. The study is based on sales growth data at the firm or industry level in the US states. The key finding of the study is that demand shifts between local areas account for large fractions of the observed variation in the unemployment and employment levels. SAmsom, 1994, considers the role of demand shifts in the determination of regional disparities of unemployment in Canada. The study is based on the shifts of the Beveridge curves and it applies quarterly data on the vacancy rates and the unemployment rates in the Canadian provinces. The study shows that the reallocation of labour resources tends to yield an increase in the unemployment rates and the vacancy rates. In particular, HyCla , 1996, has applied the measures of gross flows in the investigation of restructuring by using data from 200 US metropolitan areas.

The measures of restructuring include job reallocation. The evidence is, therefore, based on the measures of gross job creation and destruction. However, Hyclak does not measure the magnitude of restructuring by using the excess job reallocation rate. In addition, the study does not pay attention at all to gross flows of workers. The evidence is limited to manufacturing firms. Hyclak discovered empirical evidence for the notion that structural changes in labour demand have played an important role in increasing the US urban unemployment rates in the first half of the 1980s. In contrast, the following empirical investigation that applies data from the Finnish regions provides a different perspective on the role of restructuring in the determination of unemployment rates. The turnover between regional labour markets is captured by using the measures of gross flows of migration, and the investigation of the Finnish case covers all regions of the country.

\section{THEORETICAL UNDERPINNINGS}

The creation and destruction of jobs require workers to switch employers and to shuffle between employment and joblessness. This means that unemployed workers are in a state of reallocation. Reallocation of resources is indeed essential for the growth of modern economies. CABAllero and Hammour, 1994, stress that restructuring of labour resources is associated at the plant level of the economy with the adaptation of technology. In particular, Caballero and Hammour argue that the newest technology can be obtained only by creating new jobs, and the adoption of superior new technology requires the destruction of old relationships. ${ }^{8}$ Under this perspective, cyclical variation in job creation and destruction is tightly linked to technological advance and obsolescence. This means that restructuring by means of gross flows of jobs and workers revitalizes the economy. ${ }^{9}$ Moreover, CONTINI and ReVELLi, 1997, argue that the underlying movements of jobs and workers are tightly connected via the so-called 'vacancy chain'. This mechanism means that the hiring of a worker who is employed in another firm launches a whole sequence of separations and 
hirings and, thereby, adjustment of jobs and workers at the establishment level of the regions. This adjustment cannot be captured in detail by applying solely the measure of the net rate of employment change. In particular, this adjustment of labour demand can eventually cause large cumulative effects on employment and unemployment. In addition, Acemoglu, 2002, argues that churning is associated with the adaptation of new vintages of technology. Technological progress at the plant-level of the regions provides employment opportunities. In a nutshell, these features of economic progress mean that the impact of restructuring at the plant level on unemployment is an empirical matter.

\section{THE DATA}

Finland is divided into 85 sub-regions (the so-called NUTS-4 level in the European Union), the borders of which follow those of commuting districts quite closely. The yearly observations cover the period from 1989 to 1996 . The variables that are used to explain regional unemployment rates can be divided into four broad categories. Thus, there are variables that characterize: (1) the industry structure of the regions; (2) the structure of labour force and gross migration flows; (3) the intensity of restructuring at the establishment level of the regions; and (4) macroeconomic evolution of the Finnish economy during the period of the investigation. In addition, there are selected additional regional variables that include the productivity of the Finnish regions. The motivation for these variables directly arises from the existing empirical studies that have investigated the determination of the regional unemployment problem (see ElHorst, 2003). Table 1 contains a description of the variables and Appendix Table A1 provides selected descriptive statistics.

The variables that characterize the industry structure and the properties of the labour force (including gross migration flows) across regions are collected by using aggregate data from Statistics Finland. The measurement of regional gross job and worker flows is based on large longitudinal data of employees during the period from 1988 to 1996 (see BÖCKERMAN and Maliranta, 2001). This kind of data is indeed rarely available for the elaboration of regional dynamics. For instance, it is not at all possible to calculate gross flows of workers at the state level of the US economy (see SHIMER, 2001). The applied measures of gross job and worker flows cover the non-farming business sector of the Finnish economy excluding social and personal

Table 1. The description of the applied variables

\begin{tabular}{|c|c|}
\hline Variable & Definition/measurement \\
\hline$U N$ & $\begin{array}{l}\text { The number of unemployed in region } i \text { labour force in region } i \text { (i.e. unemployment is measured as fractions, e.g. } 34 \% \\
\text { unemployment is represented as } 0 \cdot 34 \text { ) }\end{array}$ \\
\hline \multicolumn{2}{|c|}{ The measures of industry structure } \\
\hline$A G R I$ & Value added by agriculture in region $i$ /GDP in region $i$ (reference) \\
\hline$M A N U$ & Value added by manufacturing industries in region $i$ GDP in region $i$ \\
\hline$M E T A$ & Value added by metal industries in region $i / \mathrm{GDP}$ in region $i$ \\
\hline ELEC & Value added by electronics in region $i$ /GDP in region $i$ \\
\hline SER V & Value added by private services in region $i$ /GDP in region $i$ \\
\hline$P U B L$ & Value added by public sector in region $i$ GDP in region $i$ \\
\hline$H I G H$ & Value added by high-tech manufacturing in region $i$ /GDP in region $i$ \\
\hline HISE & Value added by high-tech services in region $i$ /GDP in region $i$ \\
\hline \multicolumn{2}{|c|}{ The measures of labour force and gross migration flows } \\
\hline$A G E D$ & The number of employees aged from 55 to $65+$ in labour force in region $i$ /labour force in region $i$ \\
\hline UNSK & The number of employees with basic education only in labour force in region $i$ /labour force in region $i$ \\
\hline DENS & The number of employees in region $i$ divided by surface area in region $i\left(\mathrm{~m}^{2}\right)$ \\
\hline MIG1 & $\begin{array}{l}\text { Gross inward migration of employees with higher university degrees to region } i \text { /gross inward migration of employees } \\
\text { (total) to region } i\end{array}$ \\
\hline$M I G 2$ & $\begin{array}{l}\text { (Gross inward migration to region } i+\text { gross outward migration from region } i)-\mid \text { gross inward migration to region } i-\text { gross } \\
\text { outward migration from } i \mid \text { divided by average population in region } i \text {. Thus, MIG2 is an index of simultaneous gross inward } \\
\text { and outward migration. }\end{array}$ \\
\hline \multicolumn{2}{|c|}{ The measures of restructuring at the establishment level of the regions } \\
\hline$E J R$ & The excess job reallocation rate in region $i$ \\
\hline$C F$ & The churning rate in region $i$ \\
\hline \multicolumn{2}{|c|}{ The additional regional variables } \\
\hline$P R O D$ & Value added in region $i$ divided by average population in region $i$ \\
\hline$D E B T$ & Long-term municipal debt held in region $i$ divided by average population in region $i$ \\
\hline \multicolumn{2}{|c|}{ The macroeconomic indicators } \\
\hline$T E R M$ & Terms of trade (export price index divided by import price index) ${ }^{1}$ \\
\hline REAL & Real average lending rate by the Finnish banks (deflated by production price index) ${ }^{2}$ \\
\hline
\end{tabular}

Sources: 1. Statistics Finland; 2. Bank of Finland and Statistics Finland. 


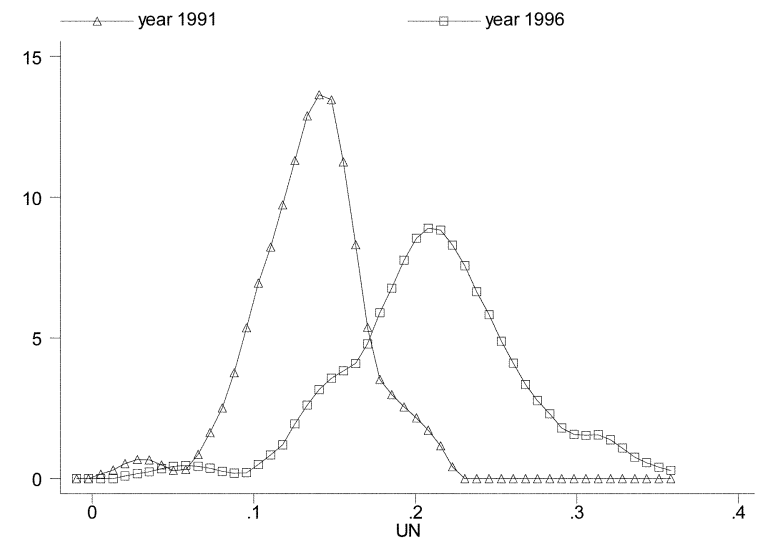

Fig. 1. Kernel density estimates for the distribution of the unemployment rate in the Finnish regions for the year 1991 and the year 1996

services, which includes more than $1 \cdot 1$ million employees in about 100,000 plants.

The following evaluation of regional labour markets in Finland is based on this linked panel data set that is created by matching the conventional economic fundamentals with the measures based on gross job and worker flows of the regions. The business cycle movements of the Finnish economy are captured by including the key macroeconomic indicators. However, the inclusion of year dummies instead of the macroeconomic indicators yields the same results as the ones reported in the following section of this study (i.e. Table 3 and Appendix Table A2), because the coefficients of the macroeconomic variables are estimated by using time-series variation only in the following regression models.

Based on the applied data, regional disparities are definitely sharp in Finland. Fig. 1 provides the Kernel density estimates for the distribution of the unemployment rate for the year 1991 (i.e. the bottom of the great slump of the early 1990s) and the year $1996 .{ }^{10}$ The figure reveals that there have not been major changes in the shape of the distributions of the unemployment rates across the Finnish regions despite the fact that there has been a sharp increase in the average unemployment rate with a rise in the dispersion of the unemployment rates at the same time. In particular, there is no empirical evidence for the bipolarization of the underlying distribution of the regional unemployment rates during the 1990s. Figs. 2 and 3 provide the distributions of the excess job reallocation rate and the churning rate in 1991 and in $1996 .{ }^{11}$ There is evidently a great deal of variation in these measures of restructuring. In particular, the excess job reallocation rate shows procyclical movements. There is also a certain amount of persistence in the applied measures of reallocation. In particular, the churning rate has been at a lower level in Eastern and Northern Finland compared with Southern Finland over the

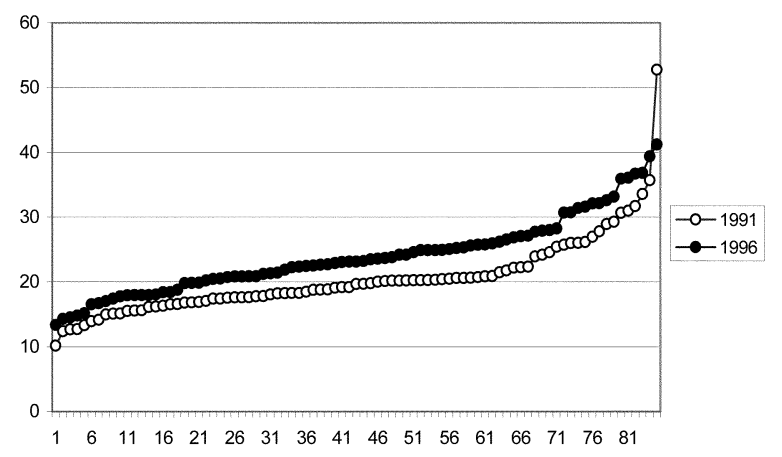

Fig. 2. The distribution of the excess job reallocation rate across the Finnish regions in 1991 and 1996

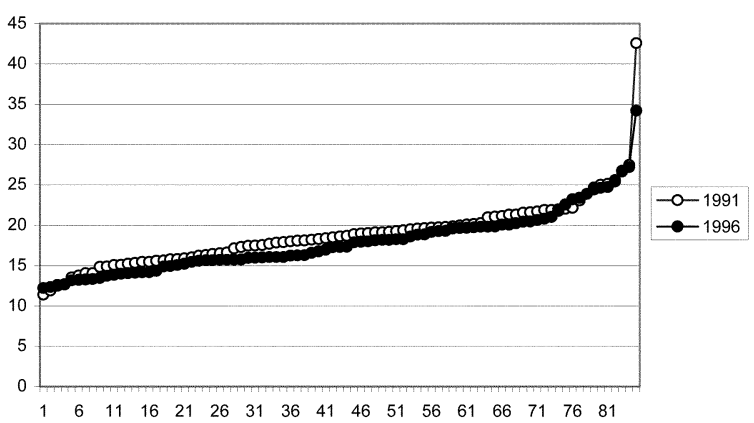

Fig. 3. The distribution of the churning rate in the Finnish regions in 1991 and 1996

Table 2. The correlation coefficients

\begin{tabular}{lrrrr}
\hline & $U N$ & $E J R$ & $C F$ & MIG2 \\
\hline$U N$ & $1 \cdot 00$ & & & \\
$E J R$ & $-0 \cdot 25$ & $1 \cdot 00$ & & \\
$C F$ & -0.50 & $0 \cdot 37$ & $1 \cdot 00$ & \\
$M I G 2$ & $0 \cdot 04$ & 0.09 & $0 \cdot 12$ & 1.00 \\
\hline
\end{tabular}

period of investigation. In contrast, the underlying regional disparities of the excess job reallocation rate have not been as persistent as the churning rate. Table 2 provides the correlation coefficients between the applied measures of restructuring and the unemployment rate. There seems to be selected preliminary empirical evidence for the perspective that an intensive pace of restructuring at the plant level of the Finnish regions is associated with low levels of the unemployment rate, which would be in conflict with the earlier empirical literature that has heavily underlined the role of restructuring as an important source of the regional unemployment problem.

\section{EMPIRICAL STRATEGY AND THE RESULTS}

Since the linked panel data of the study cover all NUTS-4 regions in Finland, the determination of 
the regional unemployment rates can be captured by applying a fixed effects model, as follows:

$$
U N_{i t}=a+v_{i}+b^{\prime} \mathbf{X}_{i t}+e_{i t}
$$

Where: $i=1, \ldots, 85 ; t=1, \ldots, 8$; and $U N$ stands for the applied measure of the unemployment rate. $\mathbf{X}$ is a vector of the conventional regional economic fundamentals and the measures of restructuring based on gross flows of jobs and workers. In addition, $v_{i}$ represents fixed effects measure by the regional dummies and $e_{i t}$ is a normally distributed error term.

The estimation results that are robust for the inclusion of the macroeconomic indicators can be summarized as follows (Table 3). The high volume of simultaneous gross inward and outward migration lowers the regional unemployment rate in Finland owing to more efficient matching between employees and establishments. The measures of job and worker turnover are indeed linked to the regional unemployment problem. In particular, the results concerning structural change indicate that the high level of restructuring in terms of excess job reallocation and churning lowers the unemployment rate. In other words, there is empirical evidence for the notion that a high degree of simultaneous gross job creation and destruction and excess worker turnover pushes down the unemployment rate in the Finnish regions. ${ }^{12}$

The empirical evidence, therefore, supports the perspective that restructuring at the establishment level of the economy in terms of the so-called 'creative destruction' by SCHUMPETER, 1942, seems to yield a decline in the regional unemployment rates in Finland. These results differ from the earlier empirical studies that emphasize the role of restructuring as an important source of the regional unemployment problem. This means that the measures that capture a plant-level adjustment of labour demand can indeed provide an interesting perspective on the nature and the consequences of the underlying reorganization of regional labour resources.

The rest of the estimation results from Table 3 can be summarized in a nutshell as follows. The industry structure is not an important determinant of the regional unemployment rates. However, the results support the view that a high share of the public sector pushes up the unemployment rate. This result is in line with a simple correlation applying aggregate data from the Finnish provinces, because the share of the public sector is higher in Eastern and Northern Finland, where the unemployment rate has indeed been higher than in Southern Finland during the past few decades. However, this feature does not necessary imply strong policy conclusions, because the role of the industry structure in modelling the determination of the unemployment rate across the Finnish regions is rather that of a control variable. As Appendix Table A1 reveals, there is a large regional variation in the share of subsectors of manufacturing industries (i.e. metal
Table 3. The results from the fixed effects model (dependent variable: $\mathrm{UN}$ )

\begin{tabular}{|c|c|c|}
\hline Variables & Coefficients & $t$-statistics \\
\hline Constant & $1 \cdot 1806^{\star \star}$ & $16 \cdot 30$ \\
\hline$M A N U$ & $0 \cdot 0077$ & $0 \cdot 16$ \\
\hline META & $0 \cdot 0073$ & $0 \cdot 17$ \\
\hline ELEC & $-0 \cdot 0944$ & $-1 \cdot 08$ \\
\hline$S E R V$ & $0 \cdot 0386$ & $0 \cdot 56$ \\
\hline PUBL & $0 \cdot 2147 \star \star$ & $2 \cdot 90$ \\
\hline$H I G H$ & $0 \cdot 0804$ & 0.92 \\
\hline HISE & $-0 \cdot 6440 \star \star$ & $-3 \cdot 99$ \\
\hline$A G E D$ & $1 \cdot 4910^{\star \star}$ & $10 \cdot 00$ \\
\hline UNSK & $-1 \cdot 3774 \star \star$ & $-21 \cdot 18$ \\
\hline DENS & $-0 \cdot 0009 \star \star$ & $-2 \cdot 04$ \\
\hline MIG1 & $0 \cdot 0161$ & $0 \cdot 40$ \\
\hline$M I G 2$ & $-1 \cdot 2519 \star \star$ & $-8 \cdot 13$ \\
\hline$E J R$ & $-0 \cdot 0243 \star \star$ & $-2 \cdot 15$ \\
\hline$C F$ & $-0 \cdot 1103 \star \star$ & $-5 \cdot 11$ \\
\hline$P R O D$ & $-0 \cdot 4956^{\star \star}$ & $-2 \cdot 42$ \\
\hline$D E B T$ & $0 \cdot 0048^{\star \star}$ & $5 \cdot 39$ \\
\hline TERM & $-0 \cdot 0060 \star \star$ & $-18 \cdot 81$ \\
\hline$R E A L$ & $-0 \cdot 0033 \star \star$ & -8.57 \\
\hline$R^{2}$ & $0 \cdot 94$ & \\
\hline$F(18,663)$ & 595.53 & \\
\hline
\end{tabular}

Notes: $\star \star(\star)$ indicates that the parameter estimate is statistically significant at the 5\%(10\%) significance level. The inclusion of year dummies instead of the macroeconomic indicators (i.e. the variables TERM and REAL) produces the same results as the ones reported in the table.

industries and electronics) across the Finnish regions. However, there is no effect from these subsectors on regional unemployment rates. An increase in the share of rapidly growing high-tech services pushes down unemployment, owing to the labour-intensive character of these activities. ${ }^{13}$ In addition, an increase in the share of so-called aged employees raises unemployment, but an increase in the share of unskilled employees pushes down the unemployment rate. ${ }^{14}$ The result remains in the case where the share of unskilled employees is divided by the average population. This seems to suggest that the so-called 'discouraged worker effect' is not behind the result that an increase in the share of unskilled employees pushes down the unemployment rate. There is empirical evidence that an increase in the density of economic activity leads to a decline in the unemployment rate. This effect is probably due to the so-called thick market externalities via regional labour market pooling. ${ }^{15}$ A high level of productivity lowers the unemployment rate. In contrast, a high level of public debt held by municipalities leads to an increase in the unemployment rate. This effect is most likely due to the fact that the high level of regional public debt tends to coincide with the high level of taxation that depresses economic activity. Another possible interpretation of the result is that a 
sluggish economic growth with an increase in unemployment yields a decline in tax revenues and therefore induces a rise in regional public debt.

In addition to an application of the earlier static model that is based on the fixed effects that are measured by the regional dummies, the regional unemployment problem can elaborated by means of the following dynamic specification: ${ }^{16}$

$$
U N_{i t}=\sum_{k=1}^{P} \alpha_{p} U N_{i, t-k}+\sum_{k=0}^{P} \beta_{p} X_{i, t-k}+\eta_{i}+\varepsilon_{i t}
$$

The model set up in equation (9) can be estimated by employing the GMM method presented by ARELLANO and BOND, 1991, for the first differenced equation. Although differencing eliminates the regional effects, it induces a negative correlation between the lagged dependent variable, $\Delta Y_{i t-1}$, and the disturbance term $\Delta \varepsilon_{i t}$. The lagged values of the variables in levels are therefore used as instruments. Strongly exogenous variables are allowed to influence the rate of regional unemployment from periods $t-1$ and $t-2$. In the case of endogenous variables, the effects are allowed to arise from the current period, $t$, and from the period $t-1$.

In the context of regional unemployment, there are three endogenous variables, viz: the excess job reallocation rate; the churning rate; and the measure of simultaneous gross migration flows across the regions of Finland. There is earlier empirical evidence that the regional excess job reallocation rates exhibit procyclical movements over the period of the investigation (see BÖCKERMAN and MALIRANTA, 2001). In particular, an increase in the unemployment rate may induce a decline in the excess job reallocation rate. This means that there is a potential two-way causal relationship between the unemployment rate and the excess job reallocation rate that needs to be taken into account. In other words, the specification is able to incorporate the dynamics and the endogeneity of the variables that are used to capture the reorganization of regional labour markets.

The estimation results of the equation (9) are reported in Appendix Table A2. The reported specification survives the Sargan test for the validity of the instruments. The estimation results support the perspective that the industry structure of the regions is not an important element in the determination of regional unemployment in Finland. In particular, the earlier conclusion about the role of simultaneous gross migration flows and the churning rate survives a dynamic specification of the relationship. In other words, there is additional empirical evidence for the notion that an intensive pace of reorganization in regional labour markets is indeed linked to the low level of unemployment in Finland. However, based on the dynamic specification reported in Appendix Table A2, there is, in fact, no empirical evidence for the view that an increase in the excess job reallocation rate is able to yield a decline in the regional unemployment rates. This result arises most likely due to the endogeneity of the excess job reallocation rate. ${ }^{17}$ Moreover, the share of unskilled employees yields a different conclusion as a lagged variable in comparison with the earlier static model that incorporates the fixed effects.

\section{CONCLUSIONS}

The study explored the determination of the unemployment rates by using data from the regions of Finland. The striking empirical finding based on gross flows of jobs and workers is that the internal and the external reorganization of labour markets lowers the unemployment rate in the Finnish regions. The essential role of restructuring in the determination of regional unemployment has some direct relevance for regional policy. In particular, these findings provide empirical support for the perspective that various public measures should not be aimed at aiding contracting plants since restructuring at the establishment level of the economy will eventually yield a lower unemployment rate. In a nutshell, the reallocation of labour resources seems to be good for regional employment.

Acknowledgements - I am grateful to Pekka Ilmakunnas and Reija Lilja for comments. In addition, I would like to thank two anonymous referees for valuable comments and suggestions. Paul A. Dillingham has kindly checked the language. The usual disclaimer applies.

\section{NOTES}

1. KiAnder and VARTia, 1996, provide a survey of the great slump of the early 1990s in Finland.

2. Pehronen, 1999, provides an empirical evaluation for the factors in the Finnish regional unemployment rates by applying cross-sectional data from 1991 that covers 13 labour districts. The study does not include a consideration of the industry structure or the elaboration of restructuring at the establishment level of the Finnish regions.

3. There have been some earlier empirical studies that investigate the effect of net in-migration on the regional unemployment rates (see ElHORST, 2003), but these studies exclude the use of gross migration flows as a measure of reorganization between regions. In particular, Chalmers and Greenwood, 1985, argue that the effect of net in-migration on regional unemployment is an empirical question and cannot be solved by theoretical considerations owing to the fact that net in-migration causes both regional labour supply and demand to increase.

4. Unlike the conventional growth rate measures, which divide employment change by lagged employment and range from $-1 \cdot 0$ to $\infty$, the applied growth rate measure ranges from $-2 \cdot 0$ to $2 \cdot 0$ and the growth rate measure is symmetric around zero. 
5. The measures of gross job and worker flows are calculated from a plant-level micro data and they are then aggregated to correspond to the so-called NUTS-4 level of the European Union.

6. In addition, the external turnover of regional labour markets is measured by the share of gross inward migration of employees with higher university degrees. The motivation for this is that the underlying mobility rates have been found to be higher for employees with a higher university education compared with employees with only basic education (see BÖCKERMAN and PiekKola, 2001).

7. There has been a large body of empirical research to find better proxies for allocative shocks. For example, LOUNGANi et al., 1990, argue that dispersion in stock prices could be used to identify allocative shocks across sectors. In particular, they claim that the stock market dispersion index is less contaminated by aggregate demand influences than the employment dispersion index by LILIEN, 1982, because sectoral stock prices are likely to react to disturbances that are perceived to be permanent by nature, which need not be true of sectoral employment changes.

8. Thus, the model neglects the notion that new technologies can also be adopted by people within their jobs.

9. In fact, the way of thinking that economic slowdowns tend to revitalize the economy was prominent in preKeynesian economic theory (see, for example, DE LONG, 1990).

10. Epanechnikov is the applied kernel density estimate. It has the property that it is the most efficient in minimizing the mean integrated squared error. DinARDo and ToBias, 2001, provide an introduction to kernel density estimates.

11. The figures may give an impression that there are certain outliers in the distributions of the excess job reallocation rate and the churning rate. However, it must be remembered that some of the NUTS-4 regions are indeed small measured by the number of employees and therefore large fluctuations can be understood as a consequence of an episode of extreme business cycle movements in Finland during the 1990s.

12. A related empirical study by ILMAKUnNAS and Pesola, 2002, discovers that a high churning flow improves matching in the Finnish regions.

13. The so-called new economy would be a dubious cure for the regional unemployment problem in Finland owing to the fact that these high-tech services typically require skills that unemployed persons lack.

14. The reported specification includes selected measures of industry structure and the measures of gross migration flows. The results concerning the variable that captures the share of unskilled employees are therefore not directly affected by the regional dispersion of the industry structure. In other words, the share of unskilled employees is not simply a proxy variable for the industry structure of the regions.

15. The models based on the ideas of the so-called new economic geography stress these effects (see, for example, Fujita et al., 1999).

16. BOND, 2002, provides a summary of dynamic panel data models.
17. The fixed effects and the GMM estimation results differ for two reasons. The first point is that the fixed effects model assumes that the explanatory variables are strictly exogenous, i.e. uncorrelated with the past, present and future realizations of $e_{i t}$. The second point is that the within-group estimator generates inconsistent estimates in dynamic specifications if the number of time periods is fixed.

\section{APPENDIX}

a. The calculation of gross flows of jobs and the net rate of employment change

Let us assume that there are two regions and two plants in the economy. The plants are called A and B. Plant A has 7 employees in Region 1 and 3 employees in Region 2 in the period $t-1$. Plant B has 1 employee in Region 1 and 4 employees in Region 2 in the period $t$. The set-up of the example is given in the following table:

\begin{tabular}{lccrrr}
\hline & \multicolumn{2}{c}{ Period $t-1$} & & \multicolumn{2}{c}{ Period $t$} \\
\cline { 2 - 3 } \cline { 5 - 6 } Plant & Region 1 & Region 2 & & Region 1 & Region 2 \\
\hline A & 7 & 3 & & 14 & 6 \\
B & 2 & 8 & & 1 & 4 \\
Sum & 9 & 11 & & 15 & 10 \\
\hline
\end{tabular}

This means that the total number of jobs has doubled in Plant A. In contrast, in the case of Plant B, the total number of jobs has decreased by $50 \%$. The applied measures of gross job flows and the net rate of employment change for the regions are as follows:

\begin{tabular}{lll}
\hline & Region 1 & Region 2 \\
\hline$J C$ & $(14-7) /((9+15) / 2)=0 \cdot 58$ & $(6-3) /((11+10) / 2)=0 \cdot 29$ \\
$J D$ & $|(1-2)| /((9+15) / 2)=0 \cdot 08$ & $|(4-8)| /((11+10) / 2)=0 \cdot 38$ \\
NET & $0 \cdot 58-0 \cdot 08=0 \cdot 5$ & $0 \cdot 29-0 \cdot 38=-0 \cdot 10$ \\
EJR & $(0 \cdot 58+0 \cdot 08)-|0 \cdot 5|=0 \cdot 17$ & $(0 \cdot 29+0 \cdot 38)-|-0 \cdot 1|)=0 \cdot 57$ \\
\hline
\end{tabular}

b. Table A1. The selected descriptive statistics

\begin{tabular}{|c|c|c|c|c|}
\hline Variables & Mean & Std & Min & Max \\
\hline$U N$ & $0 \cdot 17$ & $0 \cdot 08$ & $0 \cdot 01$ & $0 \cdot 34$ \\
\hline$A G R I$ & $0 \cdot 15$ & $0 \cdot 09$ & $0 \cdot 00$ & $0 \cdot 42$ \\
\hline$M A N U$ & $0 \cdot 32$ & $0 \cdot 12$ & 0.07 & 0.64 \\
\hline$M E T A$ & $0 \cdot 05$ & $0 \cdot 06$ & $0 \cdot 00$ & 0.54 \\
\hline ELEC & $0 \cdot 03$ & $0 \cdot 03$ & $0 \cdot 00$ & $0 \cdot 41$ \\
\hline SER V & $0 \cdot 32$ & $0 \cdot 07$ & $0 \cdot 18$ & 0.64 \\
\hline$P U B L$ & $0 \cdot 19$ & $0 \cdot 06$ & 0.07 & 0.39 \\
\hline$H I G H$ & $0 \cdot 01$ & $0 \cdot 03$ & $0 \cdot 00$ & $0 \cdot 35$ \\
\hline HISE & $0 \cdot 01$ & $0 \cdot 01$ & $0 \cdot 00$ & $0 \cdot 06$ \\
\hline$A G E D$ & $0 \cdot 11$ & $0 \cdot 02$ & $0 \cdot 07$ & $0 \cdot 21$ \\
\hline UNSK & $0 \cdot 36$ & $0 \cdot 05$ & $0 \cdot 21$ & 0.53 \\
\hline$D E N S$ & $10 \cdot 89$ & $20 \cdot 25$ & $0 \cdot 20$ & $186 \cdot 24$ \\
\hline MIG1 & $0 \cdot 15$ & $0 \cdot 03$ & 0.07 & $0 \cdot 27$ \\
\hline$M I G 2$ & $0 \cdot 05$ & $0 \cdot 02$ & $0 \cdot 02$ & $0 \cdot 11$ \\
\hline
\end{tabular}




\begin{tabular}{lrrrr} 
EJR & $0 \cdot 26$ & 0.08 & $0 \cdot 10$ & $0 \cdot 84$ \\
CF & $0 \cdot 21$ & 0.06 & $0 \cdot 07$ & 0.52 \\
PROD & $0 \cdot 20$ & 0.04 & $0 \cdot 10$ & $0 \cdot 41$ \\
DEBT & 4,667 & 1,431 & 1,374 & 10,608 \\
TERM & $97 \cdot 30$ & 3.33 & $91 \cdot 70$ & 101.50 \\
REAL & $7 \cdot 53$ & 2.72 & $4 \cdot 18$ & $12 \cdot 47$ \\
\hline
\end{tabular}

c. Table A2. The GMM estimation results (dependent variable: $\mathrm{UN}$ )

\begin{tabular}{|c|c|c|}
\hline Variables & Coefficients & $t$-statistics \\
\hline Constant & 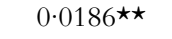 & $3 \cdot 85$ \\
\hline Dependent $_{t-1}$ & $0 \cdot 2825 \star \star$ & $2 \cdot 67$ \\
\hline$M A N U_{t-1}$ & $-0 \cdot 0394$ & $-0 \cdot 85$ \\
\hline$M A N U_{t-2}$ & -0.0092 & $-0 \cdot 19$ \\
\hline$M E T A_{t-1}$ & $0 \cdot 0252$ & $0 \cdot 48$ \\
\hline$M E T A_{t-2}$ & $0 \cdot 0140$ & $0 \cdot 28$ \\
\hline$E L E C_{t-1}$ & $0 \cdot 1076$ & $1 \cdot 47$ \\
\hline$E L E C_{t-2}$ & $-0 \cdot 0246$ & $-0 \cdot 31$ \\
\hline$S E R V_{t-1}$ & $0 \cdot 1143$ & $1 \cdot 36$ \\
\hline$S E R V_{t-2}$ & $0 \cdot 0014$ & $0 \cdot 02$ \\
\hline$P U B L_{t-1}$ & $0 \cdot 1141^{\star}$ & $1 \cdot 65$ \\
\hline$P U B L_{t-2}$ & $0 \cdot 0030$ & $0 \cdot 04$ \\
\hline$H I G H_{t-1}$ & -0.0392 & $-0 \cdot 60$ \\
\hline$H I G H_{t-2}$ & $-0 \cdot 0100$ & $-0 \cdot 19$ \\
\hline$H I S E_{t-1}$ & $-0 \cdot 0968$ & $-0 \cdot 66$ \\
\hline $\operatorname{HISE}_{t-2}$ & $-0 \cdot 0555$ & $-0 \cdot 35$ \\
\hline$A G E D_{t-1}$ & $-0 \cdot 1990$ & $-0 \cdot 76$ \\
\hline$A G E D_{t-2}$ & $0 \cdot 7298 \star \star$ & $3 \cdot 42$ \\
\hline$U N S K_{t-1}$ & $0 \cdot 8232^{\star \star}$ & $3 \cdot 19$ \\
\hline$U N S K_{t-2}$ & $-0 \cdot 1150$ & $-0 \cdot 44$ \\
\hline$D E N S_{t-1}$ & $-0 \cdot 0005$ & $-0 \cdot 40$ \\
\hline$D E N S_{t-2}$ & $0 \cdot 0003$ & $0 \cdot 30$ \\
\hline
\end{tabular}

\begin{tabular}{|c|c|c|}
\hline$M I G 1_{t-1}$ & $1 \cdot 2910 \star \star$ & $3 \cdot 12$ \\
\hline$M I G 1_{t-2}$ & $0 \cdot 7169 \star$ & $1 \cdot 78$ \\
\hline$M I G 2_{t}^{+}$ & $-5 \cdot 0125 \star \star$ & $-2 \cdot 85$ \\
\hline$M I G 2_{t-1}^{+}$ & $-4 \cdot 9203 \star \star$ & $-2 \cdot 66$ \\
\hline$E J R_{t}^{+}$ & $0 \cdot 0159$ & $0 \cdot 77$ \\
\hline \multirow{2}{*}{$\begin{array}{l}E J R_{t-1}^{+} \\
C F_{t}^{+}\end{array}$} & $0 \cdot 0130$ & $0 \cdot 95$ \\
\hline & $-0 \cdot 1121^{\star \star}$ & $-2 \cdot 55$ \\
\hline$C F_{t-1}^{+}$ & $-0 \cdot 0027$ & $-0 \cdot 10$ \\
\hline PROD $_{t-1}$ & $-0.0390 \star \star$ & $-5 \cdot 23$ \\
\hline$P R O D_{t-2}$ & $0 \cdot 0008$ & $0 \cdot 13$ \\
\hline \multirow{2}{*}{$\begin{array}{l}D E B T_{t-1} \\
D E B T_{t-2}\end{array}$} & $-0 \cdot 0001$ & $-0 \cdot 12$ \\
\hline & $-0 \cdot 0004$ & $-0 \cdot 36$ \\
\hline$T E R M_{t-1}$ & $-0 \cdot 0027 \star \star$ & $-4 \cdot 43$ \\
\hline $\begin{array}{l}\text { TER } M_{t-2} \\
R E A L\end{array}$ & $0 \cdot 0006$ & $1 \cdot 45$ \\
\hline$R E A L_{t-1}$ & $-0 \cdot 0014 \star \star$ & $-2 \cdot 16$ \\
\hline$R E A L_{t-2}$ & $0 \cdot 0059 \star \star$ & $9 \cdot 63$ \\
\hline \multicolumn{3}{|l|}{ Test statistics } \\
\hline Wald & $8140 \cdot 71$ & \\
\hline Sargan & $0 \cdot 21$ & \\
\hline $\operatorname{AR}(2)$ & $0 \cdot 98$ & \\
\hline \multicolumn{3}{|l|}{ Instruments } \\
\hline Lag length & 1 & \\
\hline \multicolumn{3}{|c|}{$\begin{aligned} & \text { Notes: } \\
&\star \star) \text { indicates that the parameter estimate is statistically } \\
& \text { significant at the } 5 \%(10 \%) \text { significance level. The reported } \\
& \text { estimation results correspond to the one-step estimates. The } \\
& \text { Wald test is a test for the joint significance of the explanatory } \\
& \text { variables. The Sargan test is a test for over-identifying } \\
& \text { restrictions and it refers to the two-step estimates. The AR(2) } \\
& \text { test refers to the second order autocorrelation of the residuals } \\
& \text { that correspond to the two-step estimates. The Sargan and } \\
& \text { the AR }(2) \text { test statistics are reported as p-values. The } \\
& \text { superscript '+' indicates that the variable is instrumented. } \\
& \text { Instruments indicate the number of lags of the dependent } \\
& \text { variable (i.e. the regional unemployment rate). The inclusion } \\
& \text { of year dummies instead of the macroeconomic indicators } \\
& \text { (i.e. the variables TERM and REAL) produces the same } \\
& \text { results as the ones reported in the table. }\end{aligned}$} \\
\hline
\end{tabular}

\section{REFERENCES}

Abraham K. G. and Katz L. F. (1986) Cyclical unemployment: sectoral shifts or aggregate disturbances?, J. Pol. Econ. 84, $367-88$.

Acemoglu D. (2002) Technical change, inequality and the labor market, J. Econ. Lit. 40, 7-72.

Arellano M. and Bond S. R. (1991) Some tests of specification for panel data: Monte Carlo evidence and an application to employment equations, Rev. Econ. Studies 58, 277-97.

Bond S. (2002) Dynamic panel data models: a guide to micro data methods and practice, Working Paper CW P09/02, Institute for Fiscal Studies, London.

Böckerman P. and Maliranta M. (2001) Regional disparities in gross job and worker flows in Finland, Finn. Econ. Pap. 14, 83-104.

Böckerman P. and Piekkola H. (2001) On whom falls the burden of restructuring? Evidence from Finland, in Jensen T. P. and Holm A. (Eds) Nordic Labour Market Research on Register Data, pp. 73-117. Nordic Council of Ministers, TemaNord 2001:593, Copenhagen.

Caballero R. (1998) Comments, in Fuhrer J. C. and Schuh S. (Eds) Beyond Shocks: What Causes Business Cycles?, pp. 338-48. Federal Reserve Bank of Boston, Conference Series 42, Boston.

Caballero R. and Hammour M. (1994) The cleansing effect of recessions, Am. Econ. Rev. 84, 1,350-68.

Chalmers J. A. and Greenwood M. J. (1985) The regional labour market adjustment process: determinants of changes in rates of labor force participation, unemployment, and migration, Ann. Reg. Sci. 19, 1-17.

Contini B. and Revelli R. (1997) Gross flows vs. net flows in the labour market: what is there to be learned?, Lab. Econ. 4, 245-63.

Davis S. J. and Haltiwanger J. (1999) Gross job flows, in Ashenfelter O. and Card D. (Eds) Handbook of Labour Economics, vol. 3B, pp. 2,711-805. North-Holland, Amsterdam.

Davis S. J., Haltiwanger J. and Schuh S. (1996) Job Creation and Destruction. MiT Press, Cambridge, MA. 
De Long J. B. (1990) Liquidation cycles: old-fashioned real business cycle theory and the Great Depression, Working Papers 3546, National Bureau of Economic Research, Cambridge, MA.

Dinardo J. and Tobias J. L. (2001) Nonparametric density and regression estimation, J. Econ. Perspectives 15, 11-28.

Elhorst J. P. (2003) The mystery of regional unemployment differentials: a survey of theoretical and empirical explanations, J. Econ. Surveys.

Fujita M., Krugman P. and Venables A. J. (1999) The Spatial Economy. Mit Press, Cambridge, MA.

Holzer H. J. (1991) Employment, unemployment and demand shifts in local labor markets, Rev. Econ. \& Statist. 73, $25-32$. Hyclak T. (1996) Structural changes in labor demand and unemployment in local labor markets, J. Reg. Science 36, 653-63.

Ilmakunnas P. and Pesola H. (2002) Matching functions and efficiency analysis, Working Papers W-308, Helsinki School of Economics.

Kiander J. and Vartia P. (1996) The great depression of the 1990s in Finland, Finn. Econ. Pap. 9, 72-88.

Lilien D. M. (1982) Sectoral shifts and cyclical unemployment, J. Pol. Econ. 80, 777-93.

Loungani P., Rush M. and Tave W. (1990) Stock market dispersion and unemployment, J. Monetary Econ. 26, 367-88.

Pehronen J. (1999) Unemployment and home-ownership, Appl. Econ. Letters 6, 263-65.

Pehronen J. and Tervo H. (1998) Persistence and turnover in regional unemployment disparities, Reg. Studies 32, $445-58$.

Samsom L. (1994) The Beveridge curve and regional disparities in Canada, Appl. Econ. 26, 937-47.

Schumpeter J. A. (1942) Capitalism, Socialism, and Democracy. Harper \& Row, Harvard.

Shimer R. (2001) The impact of young workers on the aggregate labor market, Quart. J. Econ. 116, 969-1,007.

Tervo H. (1998) The development of regional unemployment differentials in Finland in the 1990s, Finn. Econ. Pap. 11, 37-49. 